\title{
Samoistna wentrykulostomia komory trzeciej w przebiegu wodogłowia o złożonej etiologii: opis przypadku
}

\section{Spontaneous third ventriculostomy in obstructive hydrocephalus with composed aetiology: a case report}

Krzysztof Stachura, Marek Moskała

Klinika Neurochirurgii i Neurotraumatologii, Uniwersytet Jagielloński, Collegium Medicum w Krakowie

Neurologia i Neurochirurgia Polska 2010; 44, 1: 87-90

\section{Streszczenie}

Wentrykulostomia komory III jest najczęściej wykonywaną operacją neuroendoskopową, która może przywrócić zbliżone do fizjologicznych warunki krążenia płynu mózgowo-rdzeniowego w wodogłowiu obturacyjnym. Wśród ponad 70 dorosłych chorych poddanych zabiegowi autorzy zanotowali jeden przypadek samoistnej wentrykulostomii komory III. W piśmiennictwie znaleziono kilka doniesień opisujących samoistną wentrykulostomię wykazaną w różnych badaniach: w wentrykulografii, fazowo-kontrastowym badaniu rezonansu magnetycznego (RM) w opcji kinowej i autopsyjnie.

Czterdziestotrzyletnią kobietę $\mathrm{z}$ klinicznymi objawami wodogłowia i radiologicznymi cechami przewlekłego wodogłowia obturacyjnego spowodowanego zwężeniem wodociagu zakwalifikowano do wentrykulostomii komory III. W trakcie zabiegu stwierdzono, że trójkąt lejkowo-suteczkowy był rozciągnięty, a jego struktury nieobecne. W przebiegu pooperacyjnym obserwowano krótkotrwałą poprawę stanu chorej przy niezmienionym obrazie radiologicznym. Po 3 tyg. wobec nawrotu objawów wodogłowia wykonano test infuzyjny, który wykazał podwyższony opór resorpcji. Dobry efekt przyniosło założenie drenażu wewnętrznego.

Samoistną wentrykulostomię należy mieć na uwadze podczas kwalifikacji chorych do operacyjnej wentrykulostomii, zwłaszcza w przypadkach z przewlekłym przebiegiem wodogłowia obturacyjnego.

Słowa kluczowe: neuroendoskopia, wodogłowie, samoistna wentrykulostomia.

\begin{abstract}
Third ventriculostomy (TV) is the most common neuroendoscopic procedure for restoration of near physiological circulation of cerebrospinal fluid in obstructive hydrocephalus. Among 70 adults operated on using this technique, the authors encountered one case of spontaneous TV. Only a few case reports of spontaneous ventriculostomy revealed by ventriculography, flow-sensitive phase-contrast cine magnetic resonance imaging (MRI) or at autopsy have been published.

A 43-year-old woman with symptoms of hydrocephalus and signs of chronic obstructive hydrocephalus secondary to aqueductal stenosis on MRI was qualified for TV. Enlarged infundibulo-mammillary triangle with perforation was noted intraoperatively. During the postoperative course, the condition of the patient partially improved although radiological appearance remained unchanged. Three weeks later symptoms of hydrocephalus recurred and the patient underwent an infusion test which revealed increased cerebrospinal fluid outflow resistance. Implantation of a ventriculo-peritoneal shunt yielded stable improvement. Spontaneous TV should be taken into consideration during selection of patients for TV, especially in cases with chronic obstructive hydrocephalus.
\end{abstract}

Key words: neuroendoscopy, hydrocephalus, spontaneous ventriculostomy.

Adres do korespondencii: dr med. Krzysztof Stachura, Klinika Neurochirurgii i Neurotraumatologii UJ CM, ul. Botaniczna 3, 31-503 Kraków, e-mail: kkstach@poczta.onet.pl

Pracę otrzymano: 14.07.2009; przyięto do druku: 19.11.2009 


\section{Wprowadzenie}

Wentrykulostomia komory III jest obecnie najczęściej wykonywanym neuroendoskopowym zabiegiem operacyjnym. Bezpośrednie połączenie komory III z przestrzenią podpajęczynówkową u wielu chorych z wodogłowiem obturacyjnym pozwala na przywrócenie zbliżonych do fizjologicznych warunków krążenia płynu mózgowo-rdzeniowego i tym samym na uniknięcie powikłań wynikających $\mathrm{z}$ zastosowania drenażu wewnętrznego. W ciagu 8 lat w Klinice zabiegowi temu poddano ponad 70 dorosłych chorych. W jednym przypadku autorzy stwierdzili śródoperacyjnie samoistną wentrykulostomię komory III. Jedyny w polskim piśmiennictwie opis podobnego przypadku pochodzi sprzed 33 lat [1]. W innych źródłach znaleziono zaledwie kilka zbliżonych doniesień opisujących samoistną wentrykulostomię powstałą w przebiegu różnych schorzeń prowadzących do wodogłowia obturacyjnego. Wykazywano ją w wentrykulografii, fazowo-kontrastowym badaniu rezonansu magnetycznego (RM) w opcji kinowej oraz autopsyjnie [2-4]. Celem pracy jest zwrócenie uwagi na tę rzadką patologię, o której należy pamiętać podczas kwalifikacji chorych do zabiegu operacyjnej wentrykulostomii komory III.

\section{Opis przypadku}

Kobieta, 43 lata, została skierowana do Kliniki z powodu narastających od 3 lat bólów i zawrotów głowy oraz braku

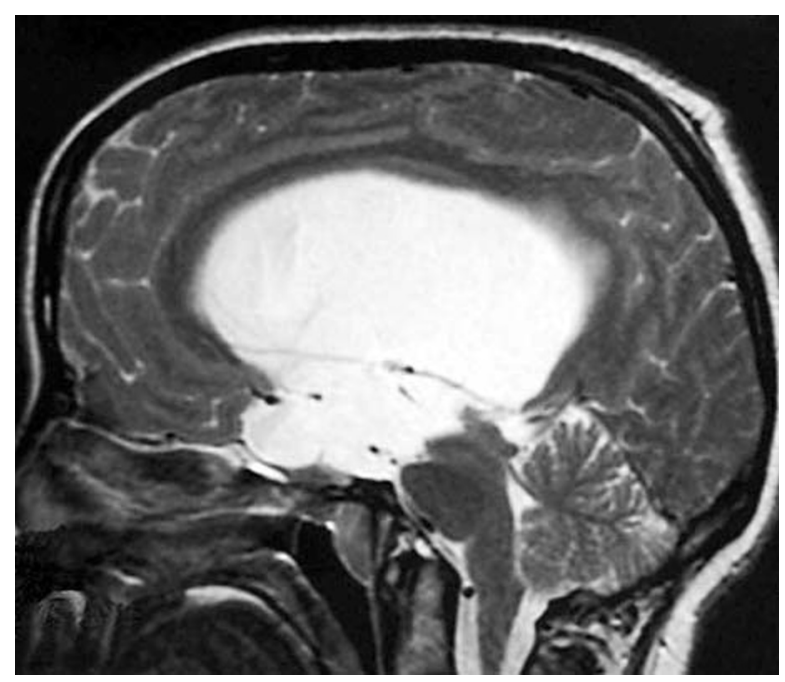

Ryc. 1. Badanie RM głowy w obrazach T2-zależnych, przekrói strzatkowy w linii środkowej. Widoczne jest zwężenie wodociqgu mózgu

Fig. 1. T2-weighted MR brain images, sagittal midline section. Aqueductal stenosis is visualized kontroli nad zwieraczami. Wykonane badania - tomografia komputerowa (TK) i RM głowy - uwidoczniły cechy przewlekłego wodogłowia obturacyjnego spowodowanego zwężeniem wodociągu mózgu (ryc. 1.). Przy przyjęciu chora była $\mathrm{w}$ kontakcie słownym, zorientowana w podstawowym zakresie, spowolniała psychoruchowo. Nie udało się uzyskać szczegółowego wywiadu. Stwierdzono nieznacznie powiększony obwód głowy, miernego stopnia wzmożenie napięcia mięśniowego w kończynach i trudności lokomocyjne. Badanie neuropsychologiczne wykazało objawy zespołu otępiennego. Biorąc pod uwagę stan kliniczny i wyniki badań neuroobrazujących, chorą zakwalifikowano do wykonania wentrykulostomii komory III.

Zabieg operacyjny przeprowadzono w znieczuleniu ogólnym z intubacją dotchawiczą, w oddechu kontrolowanym, przy użyciu anestetyków dożylnych i wziewnych. U chorej ułożonej w pozycji na wznak z głową przygiętą do klatki piersiowej wywiercono otwór trepanacyjny w punkcie Kochera po stronie prawej. Nacięto oponę twardą, skoagulowano powierzchnię mózgu i igłą Cushinga nakłuto róg czołowy komory bocznej. Uzyskano wypływ płynu mózgowo-rdzeniowego pod średnim ciśnieniem. Następnie tym samym torem do komory wprowadzono neuroendoskop (model Gaab firmy Karl Storz) zaopatrzony w optykę $0^{\circ}$. Po zlokalizowaniu poszerzonego otworu międzykomorowego końcówkę endoskopu umieszczono w komorze III. Trójkąt lejkowo-suteczkowy był w znacznym stopniu rozciagnięty, a struktury tworzące jego obszar nieobecne (ryc. 2.). Wprowadzony cewnik Fogarthy'ego i ostre, sztywne narzędzie znajdowały oparcie bezpośrednio na stoku (ryc. 3.). Wobec stwierdzenia samoistnej wentrykulostomii komory III neuroendoskop wycofano z pola operacyjnego. Otwór w oponie twardej zamknięto płatkiem materiału TachoComb, powłoki miękkie czaszki zeszyto warstwowo.

Po zabiegu chora odzyskała przytomność, nawiązała kontakt słowny z lekarzem, jej stan neurologiczny nie uległ pogorszeniu. W kolejnych dniach obserwowano częściowe wycofanie się objawów wodogłowia, przy czym obraz radiologiczny pozostawał niezmieniony. Po 3 tyg. chora wróciła do Kliniki z podobnymi jak podczas pierwszego pobytu dolegliwościami i objawami. Wykonany test infuzyjny wykazał wskaźnik oporu resorpcji wynoszący $12 \mathrm{~mm} / \mathrm{ml} / \mathrm{min}$. W związku z tym założono drenaż wewnętrzny, implantując zastawkę średniociśnieniową PS Medical. Trzyletnia obserwacja potwierdziła dobry wynik zastosowanego leczenia. 


\section{Omówienie}

Większość przypadków samoistnej wentrykulostomii komory III jest związana $\mathrm{z}$ przebiegiem przewlekłego wodogłowia obturacyjnego [2,3,5]. Komunikacja pomiędzy komorą III i przestrzenią podpajęczynówkową podstawy mózgu dokonuje się z reguły w najcieńszym miejscu dna komory, tj. między zachyłkiem lejka a ciałami suteczkowatymi. Odpowiada ono miejscu wykonywania endoskopowej wentrykulostomii komory III. Powstająca wewnętrzna przetoka płynowa stanowi alternatywną drogę krążenia płynu mózgowo-rdzeniowego. Może stwarzać to warunki do ustąpienia wodogłowia. Pęknięcie dna komory III następuje $\mathrm{w}$ rezultacie długotrwałej pulsacji płynu mózgowo-rdzeniowego [6]. Obserwacje przeprowadzone $\mathrm{w}$ trakcie zabiegów neuroendoskopowych u chorych z przewlekłym wodogłowiem obturacyjnym wykazują, że dno komory III jest bardzo cienkie, przezierne, predysponowane do pęknięcia. Taka sytuacja nie zdarza się w ostrym wodogłowiu obturacyjnym, gdzie dno komory III reaguje w sposób elastyczny na wzrost ciśnienia płynu mózgowo-rdzeniowego w układzie komorowym. Znane są przypadki innej komunikacji pomiędzy komorą III i przestrzenią podpajęczynówkową podstawy mózgu. Liis i Mervis opisali samoistną wentrykulostomię przez blaszkę graniczną [7]. Z kolei Alonso i wsp. zwrócili uwagę na występowanie samoistnej wentrykulostomii u chorych z uchyłkowatością komorową [4]. Stwierdzenie samoistnej wentrykulostomii komory III w rutynowym badaniu RM głowy jest niezwykle trudne. Rovira i wsp. opisali 3 chorych z samoistną wentrykulostomia wykrytą w fazowo-kontrastowym badaniu RM głowy w opcji kinowej [3]. Dopiero retrospektywna analiza wcześniej wykonanych u tych chorych standardowych badań RM pozwoliła na zidentyfikowanie pęknięcia dna komory III.

W opisanym przypadku wnikliwa ocena przedoperacyjnego badania RM głowy nie upoważniała do rozpoznania anomalii w obrębie dna komory III, choć autorom $z$ doświadczenia operacyjnego znane były różne jego warianty anatomiczne. $Z$ jednej strony niepełny wywiad, $\mathrm{z}$ drugiej objawy trójkomorowego wodogłowia obturacyjnego skłoniły do wykonania wentrykulostomii komory III. Utrzymywanie się poszerzonych komór bocznych i komory III przy wspófistniejącej samoistnej wentrykulostomii świadczy o utrwalonym charakterze wodogłowia. Do podobnej konkluzji doszli również Rovira i wsp. [3]. Wykazany podczas kolejnej hospitalizacji podwyższony wskaźnik oporu resorpcji wskazywał na

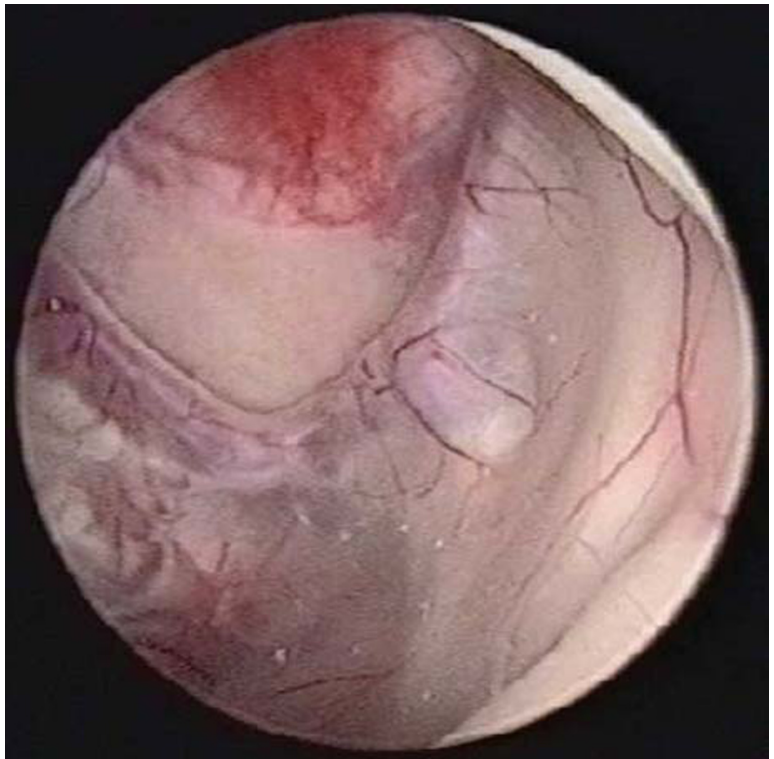

Ryc. 2. Obraz endoskopowy dna komory III. Widoczny jest ubytek dna komory trzeciej ograniczony od przodu zachyłkiem lejka, a bocznie - tętnicami mózgu tylnymi

Fig. 2. Endoscopic view of the third ventricular floor. There is a defect in the floor of the third ventricle with the infundibular recess placed anteriorly and posterior cerebral arteries located laterally

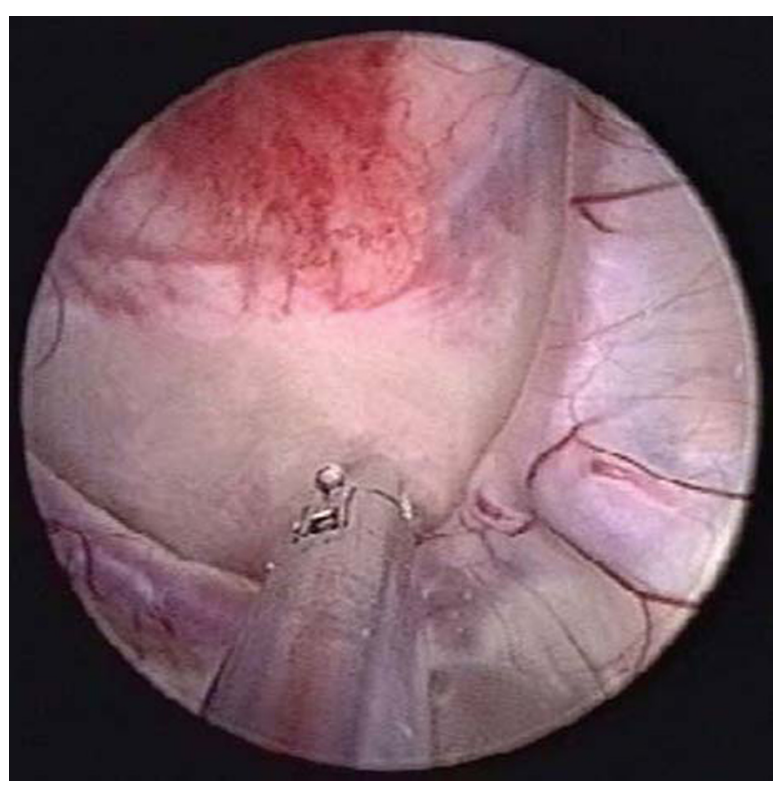

Ryc. 3. Obraz endoskopowy. Sprawdzanie drożności komunikacii z przestrzeniq podpajęczynówkową podstawy mózgu. Ostre, sztywne narzędzie oparło się 0 stok

Fig. 3. Endoscopic view. Verification of communication with basal cisterns. Sharp, rigid instrument placed adjacent to the clivus 
upośledzenie resorbcji płynu mózgowo-rdzeniowego i pozwalał na rozpoznanie złożonej etiologii wodogłowia.

Należy domniemywać, że samoistna wentrykulostomia komory III występuje częściej, niż wynikałoby to ze znanych opisów. Stosowanie badań TK i RM głowy $\mathrm{w}$ rutynowych opcjach $\mathrm{w}$ diagnostyce wodogłowia powoduje, że nie jest ona na co dzień rozpoznawana. Jak uważają Rovira i wsp., sytuację tę mogłoby zmienić szersze wykorzystanie fazowo-kontrastowego badania RM głowy w opcji kinowej [3] Obrazuje ono w sposób bezinwazyjny przepływ płynu mózgowo-rdzeniowego wywołany pulsacją serca przenoszącą się na naczynia tętnicze, kapilarne i miąższ mózgowia [8]. U chorych $z$ wodogłowiem obturacyjnym, u których wentrykulostomia komory III jest rozważana jako alternatywa drenażu wewnętrznego, badanie to może ułatwić podjęcie właściwej decyzji [8-10]. Powinno być ono przeprowadzane w przypadkach, w których można podejrzewać długotrwałe istnienie wodogłowia obturacyjnego, i u tych chorych, u których jednoznaczna ocena dna komory III jest trudna. W przedstawionym przypadku wykonanie fazowo-kontrastowego badania RM głowy w opcji kinowej było niemożliwe z przyczyn technicznych.

\section{Oświadczenie}

Autorzy zgłaszają brak konfliktu interesów.

\section{Piśmiennictwo}

1. Woźniak M., Ostrowski K., Sadowski Z. Samoistna wentrykulostomia w przebiegu wodogłowia zamkniętego o nieustalonej etiologii. Neurol Neurochir Pol 1976; 10: 675-678.

2. Miyasaka Y., Morii S., Takagi H. i wsp. A case of spontaneous 3rd ventriculostomy. No Shinkei Geka 1977; 5: 81-87.

3. Rovira A., Cappellades J., Grivé E. i wsp. Spontaneous ventriculostomy: report of three cases revealed by flow-sensitive phase-contrast cine MR imaging. AJNR Am J Neuroradiol 1999; 20: $1647-1652$.

4. Alonso A., Taboada D., Alvarez J.A. i wsp. Spontaneous ventriculostomy and ventricular diverticulum. Radiology 1979; 133: 651-654.

5. Yuen A., Bulluss K.J., Trost N. i wsp. Spontaneous third ventriculostomy. J Clin Neurosci 2008; 15: 587-590.

6. Drake J.M. Ventriculostomy for treatment of hydrocephalus. Neurosurg Clin North Am 1993; 4: 657-666.

7. Liss L., Mervis L. Spontaneous ventriculostomy through lamina terminalis with arrest of hydrocephalus. J Neurosurg 1965; 23: 211-213.

8. Nitz W.R., Bradley W.G., Watanabe A.S. i wsp. Flow dynamics of cerebrospinal fluid: assessment with phase-contrast velocity
MR imaging performer with retrospective cardiac gating. Radiology 1992; 183: 395-405.

9. Kim L.J., Feiz-Erfan I., Clatterbuck R.E. i wsp. Spontaneous ventriculostomy in a patient with obstructive hydrocephalus. Acta Neurochir 2005; 147: 219-220.

10. Naidich T.P., Altman N.R., Gonzalez-Arias S.M. Phase-contrast cine magnetic resonance imaging: normal cerebrospinal fluid oscillation and application to hydrocephalus. Neurosurg Clin North Am 1993; 4: 677-705. 